\title{
Financing of State Universities in India: A Case Study
}

\author{
C. Krishnan iD \\ School of Social Sciences and Policy, Department of Development Studies, Central University of South Bihar, Bihar-824236, India
}

krishnan@cusb.ac.in

\section{ARTICLE INFORMATION}

Received: July 30, 2020

Revised: October 17, 2020

Accepted: January 06, 2021

Published Online: March 31, 2021

\section{Keywords:}

Higher education, Merit good, Internal resource generation, University finance

DOI: 10.15415/iie.2021.91002

\begin{abstract}
The fiscal crisis facing the economy has led to withdrawal of the state from major sectors of the economy including education. With the advent of the liberalized economic policy the private sector has been playing a pivotal role in the economic development. Higher education ceases to be the 'merit good' and the universities are encouraged to mobilize resources by their own efforts rather than depending on government grants. This has impacted the financing of state and central universities across India. Actually, this paper evaluates the funding of state universities in India through a case study, taking into consideration the changing contours of financing higher education. The core idea of the study is to analyse the resource mobilization as well as its utilization by the selected university. The study is based on secondary data. The discussion on the funding pattern reveals that the university is highly dependent on state grants for their day-to-day functioning. Though the efforts to generate internal resources is picking up, the university has failed to address the long run financial crunch of the university. The study concludes that unless the universities explore alternative channels of resources mobilization, it would be difficult to offer quality education in this era of globalization.
\end{abstract}

\section{Introduction}

Like any other sectors of the economy, higher education sector is also being transformed tremendously during the last 25 years or so. Even at the global level, higher education system has been restructured with the pervading of market, offering a competing paradigm and restructuring the interplay between the Market, the State and the Universities at the advent of globalization. From a state of 'merit good, higher education has been swiftly transformed to be an internationally traded commodity. In all modern societies, universities are considered as the 'knowledge factories'. Universities are in a big way moving from the status of grant dependent institutions to self-sustaining universities by identifying their own resources and reducing their dependence on public funding and support. It is a widely accepted fact that education, the most critical engine of growth, is getting costlier and the public exchequer can hardly afford to finance the requirements of the community.

Globally, several attempts are being tried for solving the problem of cost escalation in Higher Education finance. Perhaps the most popular and most sought after technique is the switching over to the financially Sustainable Universities. In the case of India, this move has become more visible during the late 1980s and became intense during the 1990s.

The additional resources for making Universities selfsustainable, as expected, will be mobilized by resorting to donations, enhanced fee, introducing more user charges and reducing the burden of state apparatus and will create a sense of autonomy and responsibility within the educational sector.

The suggestions of two committees appointed by the Government of India shall be worth to mention here. They are the Committee under the chairmanship of Dr. D. Swaminadhan (AICTE, 1994) and the other is the Committee for Central Universities under the chairmanship of Justice K Punnayya (UGC, 1993). Though these committees were looking into the financial system of technical education institutions and central universities, the conclusions of them were almost similar. They reiterated the need for special efforts on the part of the higher education institutions to mobilize their own resources for the proper functioning of the institutions. 
It is in this context that this study is carried out with a view to analyse the functioning of the Universities in India in terms of its revenue and expenditure dimensions. The main objective of the study is to understand the sources of finances available to the university in meeting their academic and non-academic obligations. This will help us to understand whether the university has any scope for self-sustenance in the near future. With this aim mind, we have selected the largest affiliating university from the state of Kerala, viz., University of Calicut, for a detailed discussion.

\section{Importance of the Study}

The Higher Education System is witnessing a series of irreversible changes, upcoming in the form of several paradigmatic shifts from 'local' and 'national' to 'global'; 'State controlled' to 'Open market driven' and 'teacher centred' to 'learner centred' as well as 'life-long education'. The intrusion of 'market' into the landscape of higher education to interplay with universities and the State is the catalytic reagent which has triggered of the new wave (Weiler, 2001). This has witnessed the crumbling of the social democratic ideals of a widely developed welfare state with State supported higher education (Bowles and Wagman, 2001). The 'internationalization' and 'commodification' of education is the recently emerged paradigms. Each of these paradigmatic shifts have added the responsibilities and offered fresh challenges to our University system. The prominent one in this series of shifts from the perspective of economics is the source of funds. With the emergence of education as a commodity and the changing perspective of universities towards the centers of knowledge generation, the financial support they have been enjoying ever since their formation start on to dwindle and the universities are being forced to go by the directions to generate own resources (Nigavekar, 2003).

Considering the recommendations of various committees and slow growth in the release of grants from governments, the higher education institutions in India experimented with various alternatives to raise their own revenue to finance education. In Kerala also, the universities have come forward with several initiatives to enhance their financial position. Most of them are following cost-recovery measures in the form of hike in the tuition fees, starting of self-financing courses and so on. These measures have surely increased the financial resources of the universities. However, the question is whether the increased resources are used for the quality upgradation of the teaching-learning process or for some unproductive activities. So, an analysis of the method of resource generation and its utlisation in Indian universities is a meaningful effort. This is the rationale for conducting this study with special focus on universities in Kerala.

\section{Review of Literature}

Attempts to streamline the education system and introduction of unconventional methods of resource mobilization have been the subject of discussion since the initiation of new economic reforms. The international experiences have been experimented on a wider scale in the Indian context too. It is in this background that we make an attempt to review the studies carried out in this direction.

Chattopadhyay (2020) analysed the present funding pattern of Indian universities and elaborated extensively on various ways by which the universities are generating revenue. After a thorough analysis, the author came to the conclusion that public funding is the best option for achieving the three objectives of efficiency, equity and excellence in higher education.

Chatterjee and Rudra Sensarma (2018) in a study compares the funding model of Indian universities with that of world scenario. While Indian universities are heavily depending on student fees, the Western counterparts are embarking on philanthropic grants and the income from endowments. As Indian universities are totally depending on student fees, proper infrastructure could not be maintained in educational institutions that have far reaching consequences on the quality of education imparted by them. Similarly, industry-academia linkage and alumnae contribution to education are still in its embryo form in Indian universities. So, their paper suggests that the universities should go beyond the student fee to make our universities self-sustaining and able to provide quality education.

Panigrahi (2018a) through her study found that unlike centrally-funded HEIs, the State universities confront mounting expenditures, growing enrolments, and resources shortages due to the decline in public funding. They subsequently resort to higher tuition 
fees, self-financing courses, and various cost-saving measures that compromise academic quality, access to higher education by deprived groups and impact the mid and long-term growth and development of these institutions. There is need for policy interventions prioritizing development grants to provincial universities and colleges if they are to reach a level of competitiveness and quality in the near future as those institutions are rapidly deteriorating.

In another paper, Panigrahi (2018b) analysed the financing of state universities in India. She has brought into the fore the major challenges faced by state universities in harnessing new resources for ensuring quality education to the student community. These universities have miserably failed to tap the alumni contributions, industry-academia linkages, renting out university infrastructure, public private partnership activities etc., as new sources for generating additional resources. The lethargy of the university is found mainly due to the dependence on liberal grants released by the governments. So, the study suggests that the universities should focus on new areas for resource generation and proper utilization of the generated money for the provision of quality tertiary education.

Krishnan (2004) examined the role played by Distance Education Departments in the financial viability of Universities in Kerala. The study covering the major universities having distance education centres, found that without appointing regular teachers and other support system for the benefit of learners, the money raised through distance education programmes are siphoned off to meeting the overall requirements of the university concerned.

Tilak and Geetha Rani (2003), found that there is relative variation in the pattern of resource generation and its expenditure. While there is a decline in the dependence of state universities on government grants, the dependence of central universities are on the increase. They have also found that the limit of fee to be collected from the students have already attained in some of the state universities. So, alternative ways of finding resources is imminent for universities.

Ansari (1989) and Nanjundappa (1994) have also contributed to the discussion on the need for resource generation in Indian universities. In their separate studies, they emphasized the need for higher fees, donations, university-industry linkage etc., to make the university finance thick and strong. However, a critical analysis of the proposal for hike in fee and student loans can be seen in the writings of Tilak and Varghese (1991) and Tilak (1993, 1997a). As a continuation to these observations, Tilak (1997b, 2000) pointed out that state financing from its tax and non-tax sources is the best way for the provision of higher education in a developing country like India. Harman (1999) and Johnstone (1998) have also commented on the need for additional funding for higher education.

The international experience on the aspects of resource generation for educational provision varies from country to country. According to the report of the NCES (1997), the revenue generated from sales and services by the public universities forms around 22.2 per cent in the USA. While in China, the universities generate on an average 18.2 per cent of their total revenue by their own through university enterprises, educational services, research and consultancy, commissioned training, donations, logistics services, tuition fees etc. (World Bank, 1997). But in Australia, the self-generated resources forms only 5.4 per cent of the total income of the universities (CDEST, 2002). Though donation is one of the sources of resources for the universities, it accounted for only a small portion of the total resources. According to the report of DETYA (1999), donations and bequests accounted for only $1.3 \%$ of operating revenue in Australia. Whereas, in China it is only 0.8 per cent (World Bank, 1997).

Friedman (1955) and Albrecht \& Ziderman, (1992) have also studied the financing requirements of the higher education institutions. They argued for the introduction of voucher system and improvements in the quality of the education programme offered by the universities. Azad (1976) examined the possible contribution of tuition fee to the total income of the higher education institutions. He suggested differential system of tuition fees.

\section{Universities and Higher Education in Kerala}

Because of the higher levels of literacy and mass migration of skilled/unskilled labour abroad have put high demand for higher education in Kerala. The demand for more seats in colleges and setting up of more institutions are always the major agenda of agitations always in the State. All these have resulted in starting more universities and colleges throughout the state. Table 1 gives the current status of universities in Kerala. 
Table 1: Profile of Universities in Kerala.

\begin{tabular}{|c|c|c|c|c|}
\hline Sl.No. & University & $\begin{array}{l}\text { Year of } \\
\text { Establishment }\end{array}$ & Discipline & Headquarter \\
\hline 1 & Central University of Kerala & 2009 & Multi-disciplinary & Kasargode \\
\hline 2 & University of Kerala & 1937 & Multi-disciplinary & Thiruvananthapuram \\
\hline 3 & University of Calicut & 1968 & Multi-disciplinary & Malappuram \\
\hline 4 & $\begin{array}{l}\text { Cochin University of Science and } \\
\text { Technology }\end{array}$ & 1971 & Multi-disciplinary & Kochi \\
\hline 5 & Mahatma Gandhi University & 1983 & Multi-disciplinary & Kottayam \\
\hline 6 & Kannur University & 1997 & Multi-disciplinary & Kannur \\
\hline 7 & $\begin{array}{l}\text { APJ Abdul Kalam Technological } \\
\text { University }\end{array}$ & 2014 & $\begin{array}{l}\text { Engineering, Technology, } \\
\text { Management }\end{array}$ & Thiruvananthapuram \\
\hline 8 & Kerala University of Health Sciences & 2010 & $\begin{array}{l}\text { Medical, Paramedical, } \\
\text { Health Sciences. }\end{array}$ & Thrissur \\
\hline 9 & $\begin{array}{l}\text { Kerala Veterinary and Animal Sciences } \\
\text { University }\end{array}$ & 2010 & Animal sciences & Wayanad \\
\hline 10 & Kerala Agricultural University & 1972 & Agriculture, Engineering & Thrissur \\
\hline 11 & $\begin{array}{l}\text { Kerala University of Fisheries and } \\
\text { Ocean Studies }\end{array}$ & 2010 & Fisheries, Climate science & Kochi \\
\hline 12 & $\begin{array}{l}\text { National University of Advanced Legal } \\
\text { Studies }\end{array}$ & 2005 & Law & Kochi \\
\hline 13 & $\begin{array}{l}\text { Sree Sankaracharya University of } \\
\text { Sanskrit }\end{array}$ & 1994 & Sanskrit and Vedic studies & Kalady \\
\hline 14 & $\begin{array}{l}\text { Thunchath Ezhuthachan Malayalam } \\
\text { University }\end{array}$ & 2012 & $\begin{array}{l}\text { Malayalam language and } \\
\text { literature }\end{array}$ & Tirur/Malappuram \\
\hline 15 & $\begin{array}{l}\text { Kerala Kala Mandalam (Deemed } \\
\text { University) }\end{array}$ & 1999 & Performing Arts & Thrissur \\
\hline 16 & $\begin{array}{l}\text { Indian Institute of Space Science and } \\
\text { Technology (Deemed University) }\end{array}$ & 2007 & Science, Technology & Thiruvananthapuram \\
\hline
\end{tabular}

Source: Department of Higher Education, Government of Kerala

As the table reveals, Kerala has one Central University, 13 State Universities and two Deemed to be Universities. The step for setting up a State Open University is in the offing. So far, the state does not have any Private Universities.

\section{Objectives of the Study}

1. To anlalyse the nature and process of resource generation in the University of Calicut.

2. To examine the pattern of expenditure of the University of Calicut, and,

3. To identify the successful practices, if any, and suggest its replication in other institutions.

\section{Methodology}

The study is mainly based on secondary data obtained from both the published and unpublished sources. The study is limited to the University of Calicut which caters to the higher education demand of the Malabar region, the most backward both economically and socially in Kerala. It is the largest university of Kerala in terms of enrolment, area of operation and number of affiliated colleges. In that sense, the selection of the institution has its own meaning and usefulness for policy making. The data required for the study has been sourced from the Annual reports, Annual Accounts and Budget of the respective institutions.

\section{University of Calicut-A Brief Profile}

Established in 1968, the University of Calicut, caters to the higher education requirements of the most economically and socially backward region of the State. It functions in a campus area of 526 acres and provides education to more than 3 lakh student population. It is the largest university in Kerala in terms of the number 
of affiliated colleges. The service area of the university spreads over five districts. The district-wise distribution of colleges in its jurisdiction is shown in Table 2.

Table 2: District-wise Distribution of affiliated colleges of University of Calicut (2019).

\begin{tabular}{|l|l|l|l|l|}
\hline District & Government & Aided & $\begin{array}{l}\text { Self- } \\
\text { financing }\end{array}$ & Total \\
\hline Wayanad & 1 & 3 & 13 & 17 \\
\hline Kozhikode & 13 & 11 & 81 & 105 \\
\hline Malappuram & 9 & 20 & 93 & 122 \\
\hline Palakkad & 9 & 9 & 55 & 73 \\
\hline Thrissur & 9 & 17 & 48 & 74 \\
\hline Total & 41 & 60 & 290 & 391 \\
\hline
\end{tabular}

Source: University of Calicut, Annual Report 2019

The information presented in the table shows that self-financing colleges are the major types of colleges affiliated to the university. District-wise, Malappuram district has the largest number of colleges and selffinancing institutions.

\section{Nature and Structure of University Finances}

The two sources of information about university finance are their Annual Financial Statements and Budget Estimates. As a rule, the finances of the State Universities are presented under four parts in these reports on the basis of source of funds and payments there from. Under Part I, details of the non-plan funds are placed, where we get information on the nonplan grant received from state government and income generated by the university from their own sources such as conducting of examinations, income generated by the academic and other departments. The income generated from these sources are utilized for the dayto-day administration such as payment of salaries, pension, conduct of examination etc. Under Part II of the Budget estimates, information on Plan funds received from the state government, UGC and receipts from cost-based programmes are presented. As it is plan fund, it should be used only for the purpose for which it is granted. Under, Part III, the funds apportioned for some specific schemes like fellowships, scholarships, research grants, National Service Schemes etc. As in the case of plan funds, these scheme funds should also be used only for the earmarked heads. Estimates/actual under part IV, exactly speaking is neither a revenue nor an expenditure. It includes debts, deposits and advances.

In general, State Universities in Kerala have classified their sources of finance into four categories as: (i) Grants: This category includes grants from Central and State Governments, UGC and specific grants from other financing institutions on specific projects., (ii) Own Resources: This category includes income from fees and other type of revenue generated by the universities., (iii) Earmarked and NSS funds: This source deals with the receipts against funds earmarked for specific purposes like fellowships, research grants and activities of NSS., and (iv) Debts and deposits: This item comprises transaction in respect of which the University incurs a liability to repay the money received or requires a claim over the amount paid together with the repayments of the former and recoveries of the latter. Table 3 provides the information on the partwise allocation of receipts of the sample university.

Table 3: Part-wise abstract of Receipts of University of Calicut (Amount in Rs. Lakhs).

\begin{tabular}{|l|l|r|r|r|r|}
\hline \multicolumn{1}{|c|}{ Part No. } & \multicolumn{1}{|c|}{ Head } & 2017-18 & 2018-19 & 2019-20 (RE) & 2020-21(BE) \\
\hline Part I & Non-Plan & 27627.24 & 30091.43 & 30611.99 & 36200.74 \\
\hline Part II & Plan & 5737.63 & 5836.05 & 7686.89 & 7642.31 \\
\hline Part III & Earmarked Funds & 478.39 & 48.57 & 193.81 & 39.90 \\
\hline Part IV & $\begin{array}{l}\text { Debts, Deposits and } \\
\text { Advances }\end{array}$ & 4719.38 & 5494.95 & 5156.95 \\
\hline & Total & 38562.64 & 41553.23 & 43987.65 & \\
\hline
\end{tabular}

Source: University of Calicut, Budget Estimates, various years

A close look at the table reveals that Non-plan receipts constitute the major share of university finance for all the years. The budget estimates for 2020-21 estimates that 73.82 per cent of the receipts will be from non- plan sources which are composed of state government grants and internally generated resources. The growth in the total receipts and total expenditure of the university for the last seven years is given in Table 4 . 
Table 4: Total Receipts and Total Expenditure of the University (In Rs. Lakhs).

\begin{tabular}{|l|l|r|r|r|}
\hline Year & Receipts & Annual Growth Rate & Expenditure & $\begin{array}{l}\text { Annual Growth } \\
\text { Rate }\end{array}$ \\
\hline $2014-15$ & 27251.33 & & 93.65 & \\
\hline $2015-16$ & 33566.60 & 0.23 & 29806.02 & 0.18 \\
\hline $2016-17$ & 38076.29 & 0.13 & 33673.15 & 0.13 \\
\hline $2017-18$ & 38560.84 & 0.01 & 36952.54 & 0.10 \\
\hline $2018-19$ & 46024.47 & 0.19 & 45056.46 & 0.22 \\
\hline $2019-20(\mathrm{RE})$ & 43987.65 & -0.04 & 51474.43 & 0.14 \\
\hline $2020-21(\mathrm{BE})$ & 49039.91 & 0.11 & 49020.40 & -0.05 \\
\hline
\end{tabular}

Source: Ibid

It is seen from the table that the total receipts of the University is expected to increase from Rs.27251.33 lakhs in 2014-15 to Rs.49039.91 lakhs in the budget estimates for 2020-21. The growth of receipt is 79.95 per cent. Similarly the expenditure rises from Rs. 25313.89 lakhs to Rs. 49020.40 lakhs during the same period showing a growth rate of 93.65 per cent. It is an indication that the growth rate of expenditure is higher than the growth rate of revenue in the University.

In order to have a clear picture of the composition of plan and non-plan receipts of the university, Table 5 is highly useful.

Table 5: State Plan and Non Plan Grants of the University for the last seven years (in Rs. Lakhs).

\begin{tabular}{|l|l|l|r|l|}
\hline Year & Plan & \multicolumn{2}{|l|}{$\begin{array}{l}\text { Annual Growth } \\
\text { Rate }\end{array}$} & \multicolumn{2}{l|}{ Non-Plan } & \multicolumn{2}{l|}{$\begin{array}{l}\text { Annual Growth } \\
\text { Rate }\end{array}$} \\
\hline $2014-15$ & 2250.00 & \multicolumn{1}{l|l}{-} & 11492.40 & -- \\
\hline $2015-16$ & 2275.00 & 0.01 & 13790.40 & 0.20 \\
\hline $2016-17$ & 2350.00 & 0.03 & 17238.00 & 0.25 \\
\hline $2017-18$ & 2400.00 & 0.02 & 19823.70 & 0.15 \\
\hline $2018-19$ & 2500.00 & 0.04 & 20814.88 & 0.05 \\
\hline $2019-20$ & 2922.89 & 0.17 & 30611.99 & 0.47 \\
\hline $2020-21$ & 3225.32 & 0.10 & 36200.75 & 0.18 \\
\hline
\end{tabular}

Source: Ibid

A close perusal of the table shows that the annual compound growth rate of Plan receipts for the last seven years is 0.06 , while the non-plan receipts has witnessed a growth rate of 0.21 . Most often, the Non-plan grant received from the State Government is nearly about $55.09 \%$ of the total receipt. While about 33\% of the total receipts are internal generation from various fees and self-financing institutions. Salaries and pension alone contribute to $63.03 \%$ of the total expenditure. As the non-plan grant received from state government is not adequate to meet non plan expenditure, the University is compelled to use funds from own sources also for meeting non plan expenditure. To an extent the short fall is made up with the income augmented internally.

After having seen the general trend in receipts and expenditure in University of Calicut, let us now understand the sources of receipts in clear terms. The very recent data available from the university as given in Table 6 shows that around 58.33 per cent is expected from State non-plan grant. The other major sources of revenue of the university are fee from cost based programmes, Examination fees, and distance education programmes. The revenue from debt/deposit/advance deals with transactions in which the University incur liability to repay the money received or has a claim to 
recover the amount paid together with repayment of the former and the recoveries of the latter. So, it cannot be Table 6: Summary of Major sources of Receipts. considered as a real source of revenue. Table 6 provides the exact sources of revenue of the University.

\begin{tabular}{|l|l|r|r|r|r|}
\hline \multirow{2}{*}{$\begin{array}{l}\text { Sl. } \\
\text { No. }\end{array}$} & \multirow{2}{*}{ Sources } & \multicolumn{2}{|c|}{ 2019-20 (BE) } & \multicolumn{2}{c|}{ 2020-21(BE) } \\
\cline { 3 - 6 } & & $\begin{array}{l}\text { Amount } \\
\text { (Rs.Lakhs) }\end{array}$ & \multicolumn{1}{c|}{$\begin{array}{l}\text { Amount } \\
\text { (Rs.Lakhs) }\end{array}$} & \multicolumn{1}{c|}{$\%$} \\
\hline 1 & State Non-Plan Grant & 26099.00 & 54.60 & 28603.00 & 58.33 \\
\hline 2 & Debt/Deposit/Advance & 5494.95 & 11.50 & 5156.95 & 10.52 \\
\hline 3 & Receipts from Cost Based Programmes & 4606.75 & 9.64 & 3862.32 & 7.88 \\
\hline 4 & Examination & 3968.51 & 8.30 & 4383.82 & 8.94 \\
\hline 5 & State Plan Grant & 3856.00 & 8.07 & 3225.00 & 6.58 \\
\hline 6 & Other Non-Plan receipt & 3122.48 & 6.52 & 3213.93 & 6.55 \\
\hline 7 & Grant from UGC and other earmarked funds & 493.75 & 1.03 & 493.90 & 1.01 \\
\hline 8 & National Service Scheme (NSS) & 88.45 & 0.19 & 0.00 & 0.00 \\
\hline 9 & Rent/Electricity and Water charges & 0.15 & 0.15 & 101.00 & 0.21 \\
\hline & Total & 47800.89 & 100.00 & 49039.92 & 100.00 \\
\hline
\end{tabular}

Source: Ibid

As already said, the state government grant is the lion share of the receipt of the university. Resources from examination, cost based programmes and other receipts including distance education programs are the other major sources in all the years.

\section{Income from Internal Sources}

Abiding to the directions of the UGC and other Committees, the university has taken some steps to generate resources by its own efforts. These are known as internal resources or own resources, which the university has the freedom to utilize for any purpose the competent authority decides. Despite the constraints in increasing fees for services etc, University has been able to increase its income from internal sources on a steady basis during the past. The percentage growth in income generated from internal sources during the last 6 years is $65.07 \%$. The total income from internal sources has been increased from Rs. 7,799.95 lakhs in 2013-14 to Rs. 12,875.13 lakhs in 2018-19. Around $56 \%$ of the balance fund at present is kept in short term and long term fixed deposits account with a view to earn interest. Total interest income under non plan segment for the year comes to Rs. 514.67 lakhs. With the introduction of new Universities, the revenue from internal sources may get decreased in future and the same may adversely affect the financial position of the University to a large extent. Government has already taken steps to start Open University in the State from next Academic Year onwards and the expected revenue loss to the University in this regard is around 20 to 25 crore per year.

It may be interesting to go into the composition of the internal resources during these years. Major components of the internal resources are Examinations Fees, Self-Financing Institutions and Distance Education. On the average, these three major components have been contributing around 83 per cent of the resources generated by Calicut University. Examination fee contributes 38 per cent of the total own resources and it is the largest component. The second largest component is Self-Financing Courses, which contributes around 33 per cent of the internal revenue. These two components, taken together, constitute around 71 per cent of the internal resources in Calicut University. The third component is Distance Education which contributes around 13 per cent of the total internal revenue. A detailed analysis of the distance education in Kerala as portrayed by Krishnan (2012) brought out the low quality education with high fee charged by distance education departments. The universities consider distance education department as 'milch cows'. Table 7 gives the component wise origin of internal resources by the university under study.

\section{Utilization of Resources in University}

When we analyse the financing of a university, the next very important part is the way in which the 
system utilizes the resources mobilised. Similar to the presentation of the receipts of the university, the budget documents of the university present its payments in four parts., viz., part I explains the non- plan expenditure, Part II provides information on Plan expenditure, Part III explains the scheme funds and the Part IV details the information on debts, deposits and advances. Table 8 portrays the information.

Table 7: Components of Internal Resources in Calicut University 2005-06 to 2018-19 (\%).

\begin{tabular}{|l|l|l|l|l|l|l|l|l|}
\hline Year & $\begin{array}{l}\text { General } \\
\text { Administration }\end{array}$ & $\begin{array}{l}\text { Non- } \\
\text { Academic } \\
\text { Depts. }\end{array}$ & $\begin{array}{l}\text { Academic } \\
\text { Depts. }\end{array}$ & $\begin{array}{l}\text { Examination } \\
\text { Fees }\end{array}$ & $\begin{array}{l}\text { Distance } \\
\text { Education }\end{array}$ & $\begin{array}{l}\text { Self- } \\
\text { Financing } \\
\text { courses }\end{array}$ & $\begin{array}{l}\text { Capital } \\
\text { Account } \\
\text { Works }\end{array}$ & $\begin{array}{l}\text { Miscellaneous } \\
2005-06\end{array}$ \\
\hline 6.39 & 5.72 & 1 & 35.11 & 9.75 & 41.01 & 0.5 & 0.52 \\
\hline $2006-07$ & 8.28 & 4.87 & 0.56 & 37.03 & 10.73 & 37.16 & 0.56 & 0.81 \\
\hline $2007-08$ & 9.54 & 3.16 & 0.6 & 36.7 & 11.44 & 35.57 & 1.02 & 1.98 \\
\hline $2008-09$ & 12.83 & 3.19 & 0.44 & 38.37 & 13.93 & 28.31 & 0.56 & 2.37 \\
\hline $2009-10$ & 12.26 & 3.16 & 0.64 & 42.02 & 11.57 & 28.23 & 0.47 & 1.65 \\
\hline $2010-11$ & 10.73 & 3.77 & 0.82 & 40.68 & 13.72 & 28.56 & 0.47 & 1.26 \\
\hline $2011-12$ & 7.02 & 2.8 & 0.93 & 34.31 & 21.33 & 29.91 & 0.55 & 3.16 \\
\hline $2015-16$ & 8.5 & 3.2 & 0.43 & 31.35 & 18.03 & 32.69 & 0.89 & 2.9 \\
\hline $2017-18$ & 8.73 & 5.4 & 1.86 & 39.79 & 17.7 & 21.05 & 0.96 & 4.49 \\
\hline $2018-19$ & 7.42 & 3.9 & 1.65 & 40.23 & 18.02 & 27.00 & 1 & 1.03 \\
\hline Average & 9.58 & 3.8 & 0.71 & 37.75 & 13.21 & 32.68 & 0.59 & 1.67 \\
\hline
\end{tabular}

Source: Annual Accounts and Budget Estimates of respective years, Calicut University
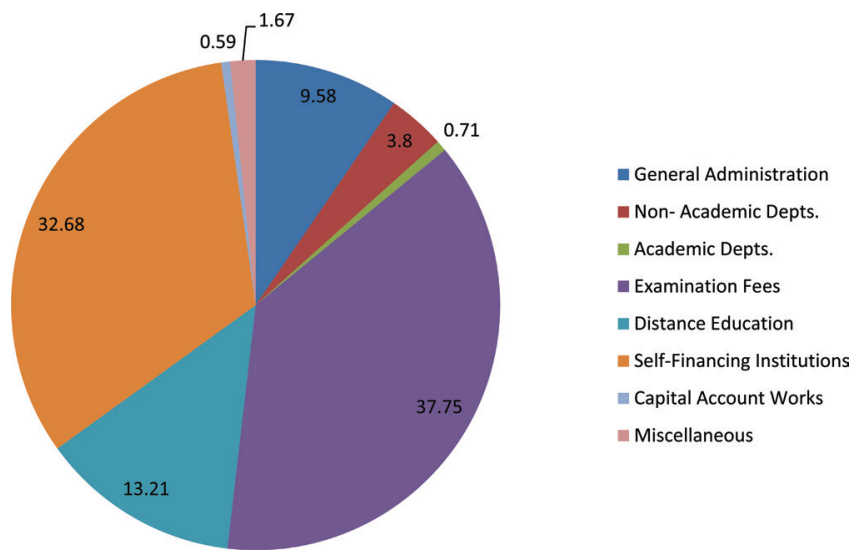

Figure 1: Sources of own Resources (Average from 2005-06 to 2018-19).

Table 8: Part-wise abstract of Payments of University of Calicut (Amount in Rs. Lakhs).

\begin{tabular}{|l|l|l|l|l|l|}
\hline Part No. & Head & $\mathbf{2 0 1 7 - 1 8}$ & $\mathbf{2 0 1 8 - 1 9}$ & 2019-20(RE) & 2020-21(BE) \\
\hline Part I & Non-Plan & 24069.53 & 23740.13 & 33640.73 & 35961.37 \\
\hline Part II & Plan & 7032.32 & 6595.06 & 11588.39 & 7754.18 \\
\hline Part III & Earmarked Funds & 747.35 & 790.18 & 498.02 & 39.90 \\
\hline Part IV & Debts, Deposits and Advances & 5100.65 & 4876.36 & 5747.29 & 5264.95 \\
\hline & Total & 36949.85 & 36001.73 & 51474.43 & 49020.40 \\
\hline
\end{tabular}

Source: Ibid 
From the table one can see that the Non-plan expenditure rose from Rs.24069.53 Lakhs to Rs.35961.37 lakhs as per their budget document. Similarly, the plan expenditure during the same period increased from Rs.7032.32 lakhs to Rs.
7757.18 lakhs. Similar hike can be seen in the case of earmarked funds and debts/deposits and advances. Now, we move on to the analysis of the expenditure categories. Table 9 gives the source wise expenditure for the latest year.

Table 9: Summary of Major Expenditure Categories (2020-21 BE).

\begin{tabular}{|l|l|l|l|l|l|}
\hline \multirow{2}{*}{ Sl. No. } & \multirow{2}{*}{ Sources } & \multicolumn{2}{|c|}{$\mathbf{2 0 2 0 - 2 1 ( B E )}$} & \multicolumn{2}{|c|}{ 2020-21(BE) } \\
\cline { 3 - 6 } & & $\begin{array}{l}\text { Amount } \\
(\text { Rs. Lakhs) }\end{array}$ & \% & $\begin{array}{l}\text { Amount } \\
(\text { Rs. Lakhs })\end{array}$ \\
\hline 1 & Salary, Pension and Other Staff Benefits & 27861.12 & 60.49 & 29992.34 & 61.18 \\
\hline 2 & Debt/Deposit/Advance & 5504.95 & 11.95 & 5264.95 & 10.74 \\
\hline 3 & Expenditure for Cost Based Programmes & 3883.45 & 8.43 & 4080.03 & 8.32 \\
\hline 4 & Examination & 208155 & 4.52 & 2235.56 & 4.56 \\
\hline 5 & Construction and Others & 4850.15 & 10.53 & 4463.47 & 9.11 \\
\hline 6 & Sports/Students Welfare & 320.83 & 0.70 & 473.35 & 0.97 \\
\hline 7 & Scholarship/Fellowship/Research programmes/Seminars & 315.05 & 0.68 & 251.55 & 0.51 \\
\hline 8 & New Schemes including Cultural/Regional Centres & 320.00 & 0.69 & 1673.00 & 3.41 \\
\hline 9 & Repairs and Maintenance (Civil and Electrical) & 228.50 & 0.50 & 244.00 & 0.50 \\
\hline 10 & Electricity charges & 280.00 & 0.61 & 280.00 & 0.57 \\
\hline 11 & National Service Scheme (NSS) & 148.95 & 0.32 & 61.45 & 0.13 \\
\hline & Equipment, Books, Furniture and Lab & 261.38 & 0.57 & -- & - \\
\hline
\end{tabular}

Source: Ibid

From the above table, it is clear that more than 60 per cent of the total expenditure of the university is for meeting the salary and pension requirements. It is to be noted that in Kerala, the retirement for the state government employees is still 56 years. A State with the highest life expectancy rate, there is every possibility that a retired employee may be drawing pension for more years than s/he received salary for working period. In order to understand more information in this regard, Table 10 is very useful.

Table 10: Number of Staff, Salary Expenditure, Number of Pensioners and Pension Amount of University of Calicut.

\begin{tabular}{|c|l|l|l|l|l|l|l|l|}
\hline \multirow{2}{*}{ Year } & \multicolumn{2}{|c|}{ Staff and salary } & \multicolumn{2}{c|}{$\begin{array}{c}\text { Pensioners and pension } \\
\text { amount }\end{array}$} & \multicolumn{5}{c|}{ Indices (base year=2005-06) } \\
\cline { 2 - 11 } & $\begin{array}{l}\text { Total no. } \\
\text { of staff }\end{array}$ & $\begin{array}{l}\text { Salary amount } \\
\text { (Rs lakh) }\end{array}$ & $\begin{array}{l}\text { No. of } \\
\text { pensioners }\end{array}$ & $\begin{array}{l}\text { Pension } \\
\text { amount } \\
\text { (Rs lakh) }\end{array}$ & Staff & Salary & Pensioners & $\begin{array}{l}\text { Pension } \\
\text { Amount }\end{array}$ \\
\hline $2005-06$ & 1728 & 2410.90 & 945 & 1084.66 & 100.00 & 100.00 & 100.00 & 100.00 \\
\hline $2009-10$ & 1673 & 4060.83 & 1280 & 1602.25 & 96.82 & 168.44 & 135.45 & 147.72 \\
\hline $2011-12$ & 1875 & 6151.60 & 1419 & 4097.27 & 108.51 & 255.16 & 150.16 & 377.75 \\
\hline $2017-18$ & 1596 & $12,097.29$ & 1924 & 8916.97 & 92.36 & 501.77 & 203.60 & 822.10 \\
\hline $2018-19$ & 1565 & 11850.00 & 1938 & 8351.80 & 90.57 & 491.52 & 205.08 & 769.99 \\
\hline $2019-20$ & 1605 & 18892.01 & 2001 & 8969.11 & 92.88 & 783.60 & 211.75 & 826.91 \\
\hline
\end{tabular}

Source: Ibid

It is seen that the number of employees is decreasing for the last several years and hence there is not much increase in salary expenses. The main reason for the considerable reduction in the Salary Bills of the 
University in the last few years is due to the engagement of large number of Contract/daily wage employees both in Teaching and Non Teaching cadre against sanctioned permanent vacancies. At present more than 100 seats each under teaching and Non Teaching Category is vacant. The work related to these seats are in some cases compensated by employing persons on contract/ daily wage basis and in many cases by giving additional works to the existing work force.

One of the main problems that will affect the financial position of the University adversely in the near future is the alarming increase in the pension bills. The expenditure on account of Pension and DCRG has been increased by $73 \%$ from 2013-14 to 201819. The total amount of pensionary benefits has been increased from Rs. 46.92 crore in 2013-14 to Rs. 81.51 crore in 2018-19. As the number of retirees from the University Service in the upcoming years is large and as many of them is higher cadre Officers drawing salary at higher scales, the situation will become worse in the near future itself and University will find it difficult to meet this commitment without sufficient additional financial assistance from the Government. Even though contributory pension system has been introduced in the University, it will take a long time to derive benefits from the same. At present University is incurring additional expenditure to the tune of around 2 crores towards National Pension Scheme contribution. More over Government has appointed a committee to study the matter of continuing the Contributory Pension System. The report of the University Finance Review Committee (2009) formed by the Government of Kerala has suggested the constitution of University Restructuring Fund with a corpus of Rs. 100 crore and granting a onetime assistance to the Universities to restructure the pension/PF administration, but no additional assistance has been received to the University so far. At present in order to meet the entire expenditure of pension, a pension fund with a corpus of minimum of Rs. 800 crore is required. With the present financial position the University will not be able to set aside such a large sum without sufficient financial assistance from the Government. The Statutory Finance Committee of the University has approved the suggestion made by the University to set aside Rs. 30 crores from its own sources for creating a pension fund subject to concurrence from and contribution by the Government to the fund at the same rate.

\section{Major Findings}

The aforesaid discussion on the finances of the University of Calicut in Kerala brings forth several interesting facts. While the universities across the world are moving towards sustaining universities, the present case study gives a quit different picture. Still the day-to-day functioning of almost all the universities of our country is conditioned by the grants of State or Central governments. Even, though these universities are active in their efforts to generate their own resources and moving towards self-sustenance, their dependence on the grants given by the State and Central governments is glaring.

It is also argued by some researchers that many of the state universities have already reached the threshold level of tuition fee and hence there is no scope for increasing fee. So, there is a limit beyond which fee income cannot go up. So, what is option for such universities? Here the interesting observation is that many of the Western universities are successful in generating huge amount by way of consultancy, sale of books, sale of service, renting our university infrastructure, academia-industry linkages, alumni contributions etc. We have already stated the experience of universities in the USA, China, Australia etc. To what extend our universities are able to harness on these opportunities is the moot question. From the in-depth study which we have conducted brings out the following major findings:

1. It is quite disheartening to note that there has hardly been any attempt for innovative practices identified for resource generation in the selected university under study.

2. The university has stuck to the worn out method of shifting of the cost burden by introducing self-financing course which are run on the basis of cost based fee structure. In the case of Calicut University, where the revenue from the Self-Financing Sector forms a major share of 33 per cent against 38 per cent from the Examination Fees.

3. Another perennial source of revenue in the University of Calicut is through the Distance Education programmes. It is also a cost based education programme.

4. Thus, the major sources of internal revenue of the university arise from their cost based courses and distance education programmes.

5. This is also a reflection of the capitalization on the increasing demand for higher education in the state as there is heavy demand for higher education due to the 
higher level of literacy and universalization of secondary and higher secondary education.

6. An analysis of the expenditure pattern of the University reveals that on an average, 60 per cent of the funds are found to be used for salary and establishment expenses, 28 per cent for pension and only less than 10 per cent for the promotion of research and scholarships and capital expenditure.

7. As a proportion of the total expenditure, plan expenditure constituted only a meager share. This has a great bearing on the quality of education.

\section{Suggestions and Conclusion}

Finding alternative sources of revenues other than what is existing now is a challenging task for the universities and other higher education institutions. From the discussion on the financing structure of the University of Calicut, we put forward the following suggestions to make the university system self-sustaining.

1. The university can profitably utilize its land resources as it has an area of 526.36 acres., in a land scarce region of Kerala.

2. The university has a student population of more than 3 lakhs every year, the publication division of the university can print and distribute text and reference books for these student community, which is now being done by a number of private publishers.

3. Though the university has professors of high caliber, it has miserably failed to encash their ability through consultancy services. So, it is high time that the university has to chart a plan for promoting consultancy services.

4. The industry-academia linkage is a missing component of the present day working of the university which is to be strengthened.

5. The university can capitalize on her large alumnae network for the development efforts on a wider scale.

6. Similar efforts are possible in other universities as well in the present context of increasing thrust on internal resource generation and slowdown in government grants for higher education.

To conclude from the data and analysis that the selfsustenance of universities, as envisaged by the European or American counterparts, still continues to be a mirage as far as the Indian Universities are concerned. The Indian Universities, in spite of the strong directions of the UGC and the Central Government, continue to depend on the grant component, with no or less efforts for identifying the fresh alternative sources of resource generation. The examination fee and the cost sharing devices of self-financing still form the major component of resources. They have not resorted to any type of the innovative techniques for generating resources such as consultancy projects or knowledge generating devices that can contribute towards their sustenance in future. It is high time that the Universities in India should resort to identify and tap innovative streams of resources that can contribute towards the future sustenance of them, which will rescue them from the excessive dependence on grants. The university has to take care of its noble role of creating quality outputs to fit into the global competitive market. At the same time the qualities of mobilization of own funds need to be re-examined. The study reveals that unless the universities explore alternative channels of resources mobilization, it would be difficult to offer quality education in this era of globalization.

\section{References}

Albrecht, D., \& Ziderman, A. (1995). Financing universities in developing countries. London: Flamer Press.

All India Council for Technical Education (1994). Report of the High Power Committee for Mobilization of Additional Resources for Technical Education. AICTE, New Delhi.

Ansari, M.M. (October 02, 1989). Resource Allocation and Financial Accountability of Universities. University News, pp.17-21.

Azad, J.L. (1976), Financing Institutions of Higher Education in India: The Need for a Realistic Fee Policy. Higher Education, 5(1), 1-7. https://doi.org/10.1007/BF01677202

Bowles, P., \& Wagmen, B. (2001). Globalization and the Welfare State: Four Hypotheses and Some Empirical Evidence. Eastern Economic Journal, 23(3), 317-336.

CDEST (2002). Finance, 2000: Selected higher education statistics. Commonwealth Department of Education Science \& Training, Commonwealth of Australia.

Chatterjee, D., \& Rudra, S. (November 18, 2018). Fund drive for varsities: Innovative funding options can keep Indian universities on the go. The Asian Age. Retrieved from https:/www.asianage.com/discourse/181118/ fund-drive-for-varsities-innovative-funding-optionscan-keep-indian-universities-on-the-go.html

Chattopadhyay, S. (January 11, 2020). Public Funding of Universities In Pursuit of Efficiency, Equity and Excellence, Economic and Political Weekly, 55(2). 
Retrieved from https://www.epw.in/journal/2020/2/ insight/public-funding-universities.html

Detya (1999). Selected higher education finance statistics. Department of Education, Training and Youth Affairs.

EUA (2008). Financially Sustainable Universities: Towards Full Cost Pricing in European Universities, European University Association.

Friedman, M. (1955). The Role of government in education. In: Solo, R.A. (ed.), Economics and the Public Interest. New Jersey: New Brunswick.

Harman, G. (1999). Vouchers or student centered funding? The 1996-1998 Australian review of higher education financing and policy. Higher education policy, 12, 219235. https://doi.org/10.1016/S0952-8733(99)00012-4

Johnstone, D. (1998). The financing and management of higher education: A status report on worldwide reforms. The World Bank Washington, D.C.

Krishnan, C. (2012). Student Support Services in Distance Higher Education in India: A Critical Appraisal. International Journal of Research in Economics and Social Sciences, 2(2), 459-472.

Krishnan, C (2004), Distance Higher Education in Kerala: Students' Assessment, Discussion paper, KRPLLD, Centre for Development Studies, Thiruvananthapuram.

Nanjundappa, D.M. (1994). Finance and Management of Higher Education, Deep and Deep, New Delhi.

NCES (1997). National center for education statistics: Finance FY97 survey, integrated Post secondary education data system. U.S. Department of Education.

Nigavekar (2003). Key note address to the UGC Golden Jubilee Seminar on Public Private Participation in Higher Education, University of Calicut, August 27-28.

Panigrahi, J. (2018a). Public Institutions in India Consider New Methods of Financing. The World View, A Blog from the Centre for International Higher Education.

Panigrahi, J. (2018b). Financing of Higher Education: Evidence from Select Case Studies of Universities in India. Aarthika Charche, 3(1), 37-46.
Tilak, J.B.G., \& Geetha Rani (2003). Changing Pattern of University Finance in India. Journal of Services Research, 2(2).

Tilak, J.B.G (1988), University Finances in India: A Review of Problems and Prospects, Higher Education, 17(6), 603-635. https://doi.org/10.1007/BF00143778

Tilak, J.B.G., \& Varghese, N.V. (1991), 'Financing Higher Education in India. Higher Education, 21, 83-101. https://doi.org/10.1007/BF00132343

Tilak, J.B.G. (1993). Financing Higher Education in India: Principles, Practice and Policy Issues. Higher Education, 26(1), 43-67. https://doi.org/10.1007/BF01575106

Tilak, J.B.G., (1997a). The Dilemma of Reforms in Financing Higher Education in India. Higher Education Policy, 10(1), 7-21. https://doi.org/10.1016/S0952-8733(96)00031-1

Tilak, J.B.G. (1997b). Lessons from Cost Recovery in Education. In: Colclough, C. (ed)

Marektising Education and Health in Developing Countries: Miracle or Mirage? (pp. 63-89). Oxford: Clarendon Press.

Tilak, J.B.G. (2000). University Finance in India: A Profile, National Institute of Educational Planning and Administration (India), NIEPA

UGC (1993). UGC Funding of Institutions of Higher Education, Report of Justice Dr. K. Punnayya Committee, 1992-92, University Grants Commission, New Delhi.

Weiler, H.N. (2001). States and Markets: Competing Paradigms for the Reform of Higher Education in Europe. Occasional Paper No. 16, National Center for the Study of Privatization in Education, Teachers College, Columbia University. Retrieved from https://ncspe. tc.columbia.edu/working-papers/OP16.pdf

World Bank (1997). China higher education reform, The World Bank, Washington, D.C. 


\section{Issues and Ideas in Education}

Chitkara University, Saraswati Kendra, SCO 160-161, Sector 9-C, Chandigarh, 160009, India

Volume 9, Issue 1

March 2021

ISSN 2320-7655

Copyright: [C 2021 C. Krishnan] This is an Open Access article published in Issues and Ideas in Education (Issues Ideas Educ.) by Chitkara University Publications. It is published with a Creative Commons AttributionCC-BY 4.0 International License. This license permits unrestricted use, distribution, and reproduction in any medium, provided the original author and source are credited. 